\title{
Nutritional evaluation of a short-horned grasshopper, Oxya hyla hyla (Serville) meal as a substitute of fishmeal in the compound diets of rohu, Labeo rohita (Hamilton)
}

\author{
Subhasish Ghosh and Dipak Kumar Mandal ${ }^{*}$ (D
}

\begin{abstract}
Background: Aqua feed demand is rising with the growth of intensive aquaculture. Fishmeal is the major conventional protein source of fish feed but its production cannot be increased due to resource limitation. Thus, suitable fishmeal (FM) substitute is a need to sustain the growth of aquaculture. Use of edible insects in animal and fish feed is gaining interest. Grasshoppers are edible insect and contain considerably high percentage of crude proteins and other nutrients. In the present study, the nutritional efficiency of Oxya hyla hyla meal as replacer of FM was evaluated by feeding Labeo rohita fingerlings with seven iso-nitrogenous compounded diets (33\% crude protein) where FM was substituted by Oxya meal (OM) at 0\%, 17\%, 33\%, 50\%, 67\%, 83\% and 100\% levels in diet 1 (D1) to diet 7 (D7) respectively. Feeding trail was continued for 100 days.

Results: Feeding experiments showed that OM-incorporated diets were acceptable to the fish and feeding on the diets they grew significantly after 100 days feeding trial in wet weight and length. Results revealed that up to 50\% replacement of FM (up to diet 4) did not affect the growth performances, condition factor of fish, apparent protein digestibility, nitrogen metabolism, food conversion ratio (FCR) and protein efficiency ratio (PER) with respect to reference diet (D1, without OM). FCR and PER were found inferior in the diets D5, D6 and D7 where more than 50\% FM was replaced. Moreover, diets regardless of FM replacement level showed no negative impact on hepato-somatic index, digesto-somatic index, relative length of gut, retention of protein, lipid and ash and on carcass compositions of the fish.

Conclusion: The results revealed that the grasshopper species, $O$. hyla hyla, might be a new protein-rich ingredient for aqua feed formulation and up to 50\% replacement of FM by OM did not affect the growth performances, feed utilisation parameters and flesh quality of the fish $L$. rohita fingerlings. Therefore, this study suggested that OM meal could be incorporated at least as partial substitute of FM in the compounded carp diet.
\end{abstract}

Keywords: Grasshopper meal, Protein source, Aqua feed, Labeo rohita

\section{Background}

Aquaculture is now a rapid growing sector in India, and to maintain its sustainable growth and productivity, proper supplementary feeding management is an essential need. Fishmeal has been used conventionally as a protein-rich ingredient in aqua feed formulation because of its compatibility in protein and amino acid requirements of fish (Alam,

\footnotetext{
* Correspondence: dkmandal.vb@gmail.com

Department of Zoology, Visva-Bharati (A Central University), Santiniketan, West Bengal 731235, India
}

\section{Springer Open}

(c) The Author(s). 2019 Open Access This article is distributed under the terms of the Creative Commons Attribution 4.0 International License (http://creativecommons.org/licenses/by/4.0/), which permits unrestricted use, distribution, and reproduction in any medium, provided you give appropriate credit to the original author(s) and the source, provide a link to the Creative Commons license, and indicate if changes were made. nabe, Kiron, \& Satoh, 1997). However, due to constrain of its uncertainty and inadequate availability and increasing cost, partial or complete replacement of fishmeal by other protein-rich feed staffs is becoming necessary. Numerous considerable research efforts have been undertaken to find out suitable substitutes of fishmeal from plant as well as animal sources (Gur, 1997; Kaushik, Coves, Dutto, \& Blanc, 2004; Middleton, Ferket, Boyd, Daniels, \& Gallagher, 2001; Mukhopadhyay \& Ray, 1999; Ojha et al., 2014; 
Rangacharyulu et al., 2003; Subhadra, Lochmann, Rawles, \& Chen, 2006; Subramanian \& Balasubramanian, 2014; Turker, Yigit, Ergun, Karaali, \& Erteken, 2005; Webster, Goodgame-Tiu, \& Tidwell, 1995; Webster, Yancey, \& Tidwell, 1992; Yang et al., 2004; Yoshitomi, Aoki, \& Oshima, 2007). Plant ingredients are cheap source of protein. However, inclusion of plant ingredients in high level or complete substitution of animal protein by plant materials may result in poor growth and feed efficiency in fish (Dabrowski, Kok, \& Takashima, 1986; Lim, 1992) due to a number of factors including the presence of anti-nutritional factors and improper amino acid balance. Many animal protein sources viz., meat and bone meal, feather meal, poultry by product meal and silkworm pupae meal have been tried as an alternative of fishmeal (Hassan \& Khan, 1999; Rangacharyulu, Paul, Nandi, Sarkar, \& Mukhopadhyay, 2000; Singh et al., 2005).

Many workers have suggested the use of grasshopper meal in animal and fish feed formulation (Alegbeleye, Obasa, Olude, Otubu, \& Jimoh, 2012; Anand, Ganguly, \& Haldar, 2008; DeFoliart, 1999; Finke, 2013; Rumpold \& Schlüter, 2013; Ueckert, Yang, \& Albin, 1972; Wang, Shao-Wei, Chuan-XI, Zhang, \& Chen, 2007). Studies revealed that grasshoppers are rich in protein, essential amino acids and other nutrients (Ganguly et al., 2013; Wang et al., 2007). Several reports suggested that dietary protein of fishmeal could be partially substituted in the fish diets with different grasshopper meal without compromising their growth, reproduction and feed utilisation efficiency (Balogun, 2011; Emehinaiye, 2012; Ganguly et al., 2014; Johri, Singh, \& Johri, 2010). Oxya hyla hyla (Serville) is a multivoltine grasshopper distributed throughout the Indian subcontinent, and this species can be farmed for biomass production (Ghosh, Haldar, \& Mandal, 2014, 2015). Moreover, the dry matter of this insect contains about $64 \%$ crude protein, good amount of essential amino acids, fat, minerals and vitamins and negligible amount of anti-nutritional factors (Ghosh, Haldar, \& Mandal, 2016). Labeo rohita is a major carp, excellent table fish and an essential candidate in aquaculture system in India. Though different grasshopper meals have been tried for inclusion in fish diets but there is no data available on the utilisation of grasshopper meal in the diet of cultivable carps. Keeping this information in mind, the present study has been undertaken for nutritional evaluation of a grasshopper species, O. hyla hyla as a partial substitute of fishmeal in the compound diets of an Indian major carp, L. rohita.

\section{Materials and methods}

\section{Procurement of grasshopper biomass}

The multivoltine grasshopper species, O. hyla hyla, was reared in the insectariums of the Department of Zoology following the method as suggested by Haldar, Das, and Gupta (1999). Five thousand adult insects (average wet weight of each individual $0.305 \pm 0.019 \mathrm{~g}$ ) were procured for Oxya meal (OM) preparation. Prior to procurement, insects were kept deprived of food for $24 \mathrm{~h}$ to make their gut empty. Wings and appendages were removed to get rid of excess chitin, and the insects were dried under a hot air oven at $40^{\circ} \mathrm{C}$ until weight became constant. The dried insects were milled and used for fish feed formulation.

\section{Estimation of proximate compositions of ingredients and feeds}

Fishmeal (FM) (Bombay duck, Harpadon nehereus), $\mathrm{OM}$, soybean meal (SBM), mustard oil cake (MOC), rice bran (RB) and wheat flour (WF) were taken as major feed ingredients. Proximate compositions of the dried ingredients were estimated following the methods of AOAC (2005). Nitrogen content was estimated using Micro-Kjeldahl digestion and distillation method, and crude protein content was calculated by multiplying the value of nitrogen content with the factor 6.25 . The crude lipid was estimated by ether extraction method using Soxhlet apparatus. After lipid extraction, sample was digested with $1.25 \% \mathrm{H}_{2} \mathrm{SO}_{4}$ and $1.25 \% \mathrm{NaOH}$ and subjected to $550 \pm 50{ }^{\circ} \mathrm{C}$ in muffle furnace till the sample was burnt to ashes and crude fibre was determined as loss on ignition of the dried lipid-free residue. Ash content was determined by subjecting the samples in muffle furnace at $550 \pm 50^{\circ} \mathrm{C}$ for about $6 \mathrm{~h}$. Carbohydrate content was calculated by difference method (100-sum of protein, fat and ash). Nitrogen-free extract (NFE) was calculated by subtracting the sum of crude protein, fat, ash and fibre from 100.

\section{Diet formulation}

Seven iso-nitrogenous, experimental diets (D1 to D7) containing about $33.62 \pm 1.76 \%$ crude protein were prepared taking $30 \%$ of the ingredients from animal sources. Of these $30 \%$ ingredients, FM to OM ratio from D1 to D7 were 30:0, 25:5, 20:10, 15:15, 10:20, 5:25 and 0:30. Therefore, FM was substituted by OM in D1 to $\mathrm{D} 7$ at a rate of $0 \%, 17 \%, 33 \%, 50 \%, 67 \%, 83 \%$ and $100 \%$ respectively. Diet 1 (D1) was without OM and was considered as reference diet (RD). The amount of SM and MOC were provided with $22 \%$ and $10 \%$ respectively in all diets. Desired crude protein level was adjusted by balancing the proportion of RB and WF following Pearson's square model (De Silva \& Anderson, 1998). Carboxy methyl cellulose (CMC) (3\%) was added as a binder, and chromic oxide (1\%) was used as non-digestible marker to estimate apparent digestibility. Vitamin premix and minerals were added (Table 2). All the ingredients were dried, milled and mixed well by adding water, after which they were passed through a hand pelletizer of $0.5 \mathrm{~mm}$ pellet diameter. The pellets were dried in hot air oven for $24 \mathrm{~h}$, crumbled and 
stored in air tight containers. Proximate compositions of the diets were estimated following the methods of AOAC (2005). Metabolisable energy (ME) of the diets was calculated considering caloric values of protein 4.5 $\mathrm{Kcal} \mathrm{g}^{-1}$, lipid $8.51 \mathrm{Kcal} \mathrm{g}^{-1}$ and carbohydrate $3.49 \mathrm{Kcal}$ $\mathrm{g}^{-1}$ according to Jauncey (1982).

\section{Experimental design}

The feeding trials of the experimental diets were conducted on L. rohita fingerlings in circular tanks of ( 26 L) filled with tap water. Fingerlings were procured from local fish farm at Santiniketan, West Bengal, and acclimatised to aquarium conditions and supplementary feeding for 20 days. After acclimation fingerlings were weighed to record initial weight. Fingerlings (average initial weight $1.50 \pm 0.19 \mathrm{~g}$ ) were randomly distributed to the circular tanks at 20 fish in each tank. Experiments were conducted in triplicate for each dietary treatment and continued for 100 days. Fish were fed with known amount of feed at 3\% body weight once daily at $10.00 \mathrm{am}$. The amount of feed was adjusted with increase of body weight in every 15-day interval. Fish were allowed to feed for $4 \mathrm{~h}$, and uneaten feeds were collected, oven dried, weighed and subjected to further analysis. Experimental tanks were kept under continuous aeration to avoid oxygen deficiency. About $50 \%$ water of the tank was changed in every alternate day and was scrubbed once a week to prevent algal growth. Water quality was checked throughout the experiment period. Faecal matters were collected before providing feeds by careful siphoning method (Spyridakis, Metailler, Gabaudan, \& Riaza, 1989) and were oven dried at $60^{\circ} \mathrm{C}$ and used for analysis.

\section{Water parameter analysis}

Water temperature, $\mathrm{pH}$, dissolved oxygen (DO) and hardness of experimental tanks were estimated in every fortnight following the methods of APHA (1990). Water temperature was in the range of 25.4 to $30.5^{\circ} \mathrm{C}$, $\mathrm{pH} 7.14$ to 7.61 , DO 4.14 to $7.82 \mathrm{mg} \mathrm{L}^{-1}$ and hardness was 172.4 to $189.6 \mathrm{mg} \mathrm{L}^{-1}$.

\section{Estimation of growth performance and survival rate}

Growth performances of the fingerlings were recorded as percentage of wet weight and length gain, percent of specific growth rate (\%SGR), percent of average daily weight gain (\%ADG) and condition factor (K). Survival rate was estimated as percent of surviving fish. The parameters were measured following the methods of De Silva and Anderson (1998) and Moyle and Cech Jr (1996) and were calculated as follows:

$$
\text { Weight gain }(\%)=100 \times \frac{\left(\mathrm{Wt}_{2}-\mathrm{Wt}_{1}\right)}{\mathrm{Wt}_{1}}
$$

Condition factors $(\mathrm{K})=\frac{\text { weight }(\mathrm{g})}{\text { length }(\mathrm{cm})^{3}} \times 100$

Specific growth rate $\left(\mathrm{SGR} \%\right.$ day $\left.^{-1}\right)=100 \times \frac{\left(\mathrm{InWt}_{2}-\mathrm{InWt}_{1}\right)}{\left(\mathrm{t}_{2}-\mathrm{t}_{1}\right)}$

Average daily weight gain (\%ADG)

$$
=100 \times \frac{\left(\mathrm{Wt}_{2}-\mathrm{Wt}_{1}\right)}{\mathrm{Wt}_{1} \times\left(\mathrm{t}_{2}-\mathrm{t}_{1}\right)}
$$

where $\mathrm{Wt}_{2}=$ final wet weight, $\mathrm{Wt}_{1}=$ initial wet weight and $t_{2}-t_{1}=$ period of experiment.

Survival rate $(\%)=100 \times \frac{\text { total number of surviving fish }}{\text { total number of fish stocked }}$

\section{Estimation of feed utilisation indices}

Feed utilisation indices such as feed conversion ratio (FCR) and protein efficiency ratio (PER) were estimated following the methods of De Silva and Anderson (1998). Protein retention value (PRV) and lipid retention value (LRV) were estimated following the method of Xie et al. (2011). Nitrogen metabolism $(\mathrm{Nm})$ was calculated according to Jamabo and Alfred-Ockiya (2008).

Apparent protein digestibility (APD) was estimated by estimating chromic oxide in the diets and faeces following the spectrophometric method (Divakaran, Leonard, \& Ian, 2002). Protein levels were estimated in the diets and faecal samples following AOAC (2005) methods. Apparent protein digestibility (APD) value was then calculated by using the formulae (De Silva \& Anderson, 1998) as follows:

Feed conversion ratio $(\mathrm{FCR})=\frac{\text { dry weight of feed consumed }(\mathrm{g})}{\text { wet weight gain }(\mathrm{g})}$

Protein efficiency ratio $($ PER $)=\frac{\text { wet weight gain }(g)}{\text { crude protein fed }(g)}$

Protein retention value $(\mathrm{PRV})=100 \times \frac{\text { fish protein gain }(\mathrm{g})}{\text { protein intake }(\mathrm{g})}$

Lipid retention value $(\mathrm{LRV})=100 \times \frac{\text { fish lipid gain }(\mathrm{g})}{\text { lipid intake }(\mathrm{g})}$

Nitrogen metabolism $(\mathrm{Nm})=\frac{0.54 \times\left(\mathrm{Wt}_{2}-\mathrm{Wt}_{1}\right) \times \mathrm{t}}{2}$

[where $\mathrm{Wt}_{1}=$ initial weight, $\mathrm{Wt}_{2}=$ final weight, and $\mathrm{t}=$ number of days]

Apparent protein digestibility (APD)

$$
=100-\left(\frac{\% \text { chromium in food }}{\% \text { chromium in faeces }} \times \frac{\% \text { Protein in faeces }}{\% \text { Protein in food }}\right)
$$

\section{Estimation of body indices, carcass composition}

Hepatosomatic index (HSI), relative length of gut (RLG) and digesto-somatic index (DSI) were 
Table 1 Proximate composition of feed ingredients (\% of dry matter)

\begin{tabular}{lllllll}
\hline Components & OM & FM & SBM & MOC & RB & WF \\
\hline Crude protein & $64.67 \pm 1.61$ & $55.30 \pm 2.50$ & $37.64 \pm 2.48$ & $35.60 \pm 1.43$ & $13.44 \pm 0.65$ & $10.75 \pm 0.23$ \\
Crude lipids & $2.58 \pm 0.09$ & $10.32 \pm 1.08$ & $5.36 \pm 0.05$ & $8.91 \pm 0.87$ & $5.04 \pm 0.11$ & $0.92 \pm 0.04$ \\
Crude fibre & $9.23 \pm 0.70$ & $4.10 \pm 0.40$ & $7.56 \pm 0.13$ & $5.35 \pm 0.10$ & $22.65 \pm 0.40$ & $0.81 \pm 0.06$ \\
Ash & $4.59 \pm 0.18$ & $15.59 \pm 0.34$ & $5.59 \pm 0.53$ & $8.36 \pm 1.30$ & $21.57 \pm 0.42$ & $0.55 \pm 0.03$ \\
NFE & $18.94 \pm 1.76$ & $14.61 \pm 2.07$ & $45.88 \pm 4.65$ & $40.97 \pm 1.48$ & $37.14 \pm 1.06$ & $86.89 \pm 0.16$
\end{tabular}

Means with \pm SD are values of triplicate groups. OM Oxya meal, $F M$ fishmeal, SBM soybean meal, MOC mustard oil cake, RB rice bran, WF wheat flour, NFE nitrogen-free extract

examined, following the methods of Xie et al. (2011). Carcass compositions (moisture, protein, lipid and ash content as \% of wet weight of tissue) of the fish were estimated following the methods of AOAC (2005).

Hepatosomatic index $(\mathrm{HSI})=100 \times \frac{\text { liver weight }(\mathrm{g})}{\text { weight of the fish }(\mathrm{g})}$

Relative length of Gut $(\mathrm{RLG})=\frac{\text { Gut length }(\mathrm{cm})}{\text { Total length of the fish }(\mathrm{cm})}$

Digesto-somatic index (DSI)

$$
=100 \times \frac{\text { wet weight of digestive tract }(\mathrm{g})}{\text { wet weight of the fish }(\mathrm{g})}
$$

\section{Statistical analysis}

Values were presented as means \pm standard deviation (SD). A one-way analysis of variance (ANOVA) was used to compare the values obtained for the different parameters using Microsoft excel 2007 software. Duncan's multiple range tests (DMRT) were used to determine whether mean values differed significantly or not. Significance was accepted at probabilities of 0.05 or less.

\section{Results}

Proximate composition of ingredients and feeds

Proximate compositions of the feed ingredients are represented in Table 1. Results revealed that crude protein content of OM $(64.67 \pm 1.61 \%)$ was higher than FM $(55.30 \pm$ 2.50\%). SBM and MOC contain about $37.64 \%$ and $35.6 \%$ crude protein on dry matter basis. The proximate

Table 2 Ingredients and proximate composition of the formulated diets (\%)

\begin{tabular}{|c|c|c|c|c|c|c|c|}
\hline \multirow[t]{2}{*}{ Ingredient (\%) } & \multirow{2}{*}{$\begin{array}{l}\text { RD } \\
\text { D1 }\end{array}$} & \multicolumn{6}{|l|}{$\mathrm{TD}$} \\
\hline & & $\mathrm{D} 2$ & D3 & D4 & D5 & D6 & D7 \\
\hline Oxya meal & 0 & 5 & 10 & 15 & 20 & 25 & 30 \\
\hline Fishmeal & 30 & 25 & 20 & 15 & 10 & 5 & 0 \\
\hline Soybean meal & 10 & 10 & 10 & 10 & 10 & 10 & 10 \\
\hline Mustard oil cake & 22 & 22 & 22 & 22 & 22 & 22 & 22 \\
\hline Rice bran & 25 & 30 & 12 & 4 & 10 & 12 & 13 \\
\hline Wheat flour & 8 & 3 & 21 & 29 & 23 & 21 & 20 \\
\hline CMC & 3 & 3 & 3 & 3 & 3 & 3 & 3 \\
\hline Vitamin and minerals & 1 & 1 & 1 & 1 & 1 & 1 & 1 \\
\hline Chromic oxide & 1 & 1 & 1 & 1 & 1 & 1 & 1 \\
\hline \multicolumn{8}{|c|}{ Proximate composition (\% of dry matter) } \\
\hline Crude protein & $33.15 \pm 1.69$ & $33.81 \pm 1.70$ & $33.08 \pm 1.72$ & $33.55 \pm 1.86$ & $33.33 \pm 1.97$ & $34.16 \pm 1.87$ & $34.23 \pm 1.70$ \\
\hline Crude lipid & $6.84 \pm 0.21$ & $6.76 \pm 0.44$ & $5.78 \pm 0.48$ & $5.40 \pm 0.43$ & $5.05 \pm 0.86$ & $4.64 \pm 0.50$ & $4.24 \pm 0.32$ \\
\hline Carbohydrate & $48.05 \pm 1.80$ & $46.47 \pm 1.82$ & $51.97 \pm 1.79$ & $52.28 \pm 1.94$ & $52.99 \pm 1.99$ & $53.93 \pm 2.08$ & $54.72 \pm 1.70$ \\
\hline Ash & $11.97 \pm 0.45$ & $12.95 \pm 0.35$ & $9.17 \pm 0.32$ & $8.78 \pm 0.43$ & $8.62 \pm 0.47$ & $7.26 \pm 0.39$ & $6.81 \pm 0.39$ \\
\hline Crude fibre & $8.62 \pm 0.33$ & $10.05 \pm 0.24$ & $7.17 \pm 0.50$ & $7.35 \pm 0.48$ & $7.82 \pm 0.64$ & $7.67 \pm 0.44$ & $7.92 \pm 0.76$ \\
\hline Nitrogen-free extract & $39.43 \pm 1.92$ & $36.42 \pm 1.78$ & $44.80 \pm 1.87$ & $44.93 \pm 1.80$ & $45.17 \pm 1.99$ & $46.27 \pm 2.18$ & $46.81 \pm 1.89$ \\
\hline ME (Kcal $\left.100 \mathrm{~g}^{-1}\right)$ & $344.96 \pm 2.32$ & $336.81 \pm 3.36$ & $354.42 \pm 3.92$ & $353.68 \pm 3.26$ & $350.68 \pm 3.36$ & $354.71 \pm 3.82$ & $353.46 \pm 2.60$ \\
\hline
\end{tabular}

Means with \pm SD are values of triplicate groups. $R D$ reference diet; TD test diet; CMC carboxy methyl cellulose, vitamin and mineral mixture (Supradyn, Abbott Healthcare Pvt. Ltd., Mumbai, India); ME metabolised energy (Kcal $100 \mathrm{~g}^{-1}$ ) 
Table 3 Growth parameters, condition factor and survival rate of L. rohita fingerlings after 100 days feeding

\begin{tabular}{|c|c|c|c|c|c|c|c|}
\hline & \multirow{2}{*}{$\begin{array}{l}\text { RD } \\
\text { D1 }\end{array}$} & \multicolumn{6}{|l|}{$\mathrm{TD}$} \\
\hline & & $\mathrm{D} 2$ & D3 & D4 & D5 & D6 & D7 \\
\hline Length gain (\%) & $33.71 \pm 1.62^{a}$ & $32.40 \pm 5.56^{\mathrm{a}}$ & $31.61 \pm 3.01^{a}$ & $31.94 \pm 3.53^{\mathrm{a}}$ & $27.34 \pm 2.65^{b}$ & $29.82 \pm 2.61^{b}$ & $28.26 \pm 1.91^{b}$ \\
\hline Weight gain (\%) & $155.85 \pm 29.61^{a}$ & $158.05 \pm 27.07^{a}$ & $164.72 \pm 20.48^{\mathrm{a}}$ & $177.03 \pm 24.55^{\mathrm{a}}$ & $144.90 \pm 30.33^{b}$ & $146.11 \pm 31.04^{b}$ & $140.79 \pm 34.13^{b}$ \\
\hline K & $1.79 \pm 0.15$ & $1.80 \pm 0.08$ & $1.78 \pm 0.11$ & $1.77 \pm 0.14$ & $1.72 \pm 0.15$ & $1.76 \pm 0.19$ & $1.77 \pm 0.11$ \\
\hline SGR (\%) & $0.41 \pm 0.06^{\mathrm{a}}$ & $0.42 \pm 0.06^{\mathrm{a}}$ & $0.43 \pm 0.04^{a}$ & $0.44 \pm 0.04^{a}$ & $0.37 \pm 0.05^{b}$ & $0.39 \pm 0.07^{b}$ & $0.36 \pm 0.06^{\mathrm{b}}$ \\
\hline ADG (\%) & $1.63 \pm 0.41^{\mathrm{a}}$ & $1.65 \pm 0.38^{\mathrm{a}}$ & $1.69 \pm 0.23^{\mathrm{a}}$ & $1.79 \pm 0.25^{\mathrm{a}}$ & $1.40 \pm 0.29^{b}$ & $1.50 \pm 0.41^{b}$ & $1.62 \pm 0.38^{b}$ \\
\hline Survival rate & $81.67 \pm 5.77^{b}$ & $88.33 \pm 2.89^{a}$ & $88.33 \pm 2.89^{a}$ & $88.67 \pm 2.89^{a}$ & $88.33 \pm 2.89^{a}$ & $88.33 \pm 2.89^{a}$ & $80.00 \pm 5.00^{b}$ \\
\hline
\end{tabular}

Means with \pm SD are values of triplicate groups. Figures in the same row with same superscripts are not significantly different (one-way ANOVA followed by DMRT, $p>0.05)$. $R D$ reference diet, $T D$ test diet, $K$ condition factor, $S G R$ specific growth rate, $A D G$ average daily weight gain

compositions of the prepared diets are presented in Table 2 which shows that diets are iso-nitrogenous containing about $33 \%$ crude protein.

\section{Growth performance and survival rate of the fish}

During feeding experiments, it has been noticed that OM-incorporated experimental diets were acceptable and palatable to the fish and fish grew significantly $(p<0.05)$ from their initial wet weight and length after 100 days feeding. The results showed that feeding on OM-incorporated diets caused no significant differences in condition factor, growth performances and percent of survival among the fish of different groups (Table 3). SGR (\%day ${ }^{-1}$ ) and ADG (\%) of the fish fed with experimental diets and reference diet (D1) were similar. Wet weight and length gain the fish fed with D3 and D4 were better than the fish fed on reference (D1) diet but the fish fed on D6 and D7 diets containing higher level of OM showed inferior results.

\section{Feed quality and feed utilisation}

Data obtained regarding feed quality and feed utilisation assessment were presented in Table 4. The results (Table 4) showed that FCR of the experimental diets were not affected rather improved in D3 and D4 diets. Similarly, PER was improved in D3 and D4 diets. However, feeds (D5, D6 and D7) which were prepared with higher proportion of OM showed significantly $(p<0.05)$ reduction in PER and $\mathrm{Nm}$. Protein and lipid retention values in the fish fed on test diets did not differ significantly $(p<0.05)$ from the control. APD of the feeds D2, D3 and D4 was similar to reference diet (D1) but APD reduced significantly in D5 to D7.

\section{HIS, RLG, DSI and carcass composition}

Feeding experiments showed that feeding on OM-incorporated diets had no negative impact on HSI, RLG and DSI (Table 5). The proximate compositions of carcass on wet matter basis of the fish fed on experimental diets revealed that carcass protein and lipid contents were significantly increased in the fish fed on D2, D3 and D4 diets than D1 fed fish. However, in fish fed with D5 to D7 diets carcass lipid content was decreased (Table 6).

\section{Discussion}

Protein is an essential and most important component of a fish feed, and it should be at optimum level to obtain the best growth performance of fish. The conventional protein source for aqua-feed industry is fishmeal. Due to resource limitation, fishmeal production is inadequate with respect to its demand and expensive. Thus, cheaper and efficient substitutes of fishmeal are necessary. Soybean meal, rapeseed meal and oil cakes are

Table 4 Feed utilisation parameters of L. rohita fingerlings after 100 days of feeding

\begin{tabular}{llllllll}
\hline & RD & TD & & & \\
\cline { 2 - 7 } & D1 & D2 & D3 & D4 & D5 & D6 & D7 \\
\hline FCR & $1.89 \pm 0.38^{\mathrm{a}}$ & $1.99 \pm 0.48^{\mathrm{a}}$ & $1.82 \pm 0.22^{\mathrm{b}}$ & $1.72 \pm 0.20^{\mathrm{b}}$ & $2.19 \pm 0.40^{\mathrm{a}}$ & $2.05 \pm 0.39^{\mathrm{a}}$ & $1.95 \pm 0.41^{\mathrm{a}}$ \\
PER & $1.59 \pm 0.08^{\mathrm{b}}$ & $1.62 \pm 0.09^{\mathrm{a}}$ & $1.67 \pm 0.10^{\mathrm{a}}$ & $1.74 \pm 0.12^{\mathrm{a}}$ & $1.36 \pm 0.07^{\mathrm{c}}$ & $1.40 \pm 0.06^{\mathrm{c}}$ & $1.54 \pm 0.17^{\mathrm{b}}$ \\
PRV & $1.45 \pm 0.17$ & $1.43 \pm 0.14$ & $1.46 \pm 0.24$ & $1.48 \pm 0.23$ & $1.46 \pm 0.31$ & $1.44 \pm 0.29$ & $1.46 \pm 0.37$ \\
LRV & $2.68 \pm 0.27$ & $2.63 \pm 0.38$ & $2.53 \pm 0.39$ & $2.73 \pm 0.30$ & $2.50 \pm 0.39$ & $2.72 \pm 0.44$ & $2.61 \pm 0.56$ \\
ARV & $1.09 \pm 0.16$ & $1.13 \pm 0.20$ & $1.09 \pm 0.30$ & $1.15 \pm 0.20$ & $1.27 \pm 0.22$ & $1.27 \pm 0.23$ & $1.20 \pm 0.17$ \\
Nm & $64.04 \pm 6.61^{\mathrm{a}}$ & $58.81 \pm 6.88^{\mathrm{b}}$ & $65.80 \pm 3.20^{\mathrm{a}}$ & $67.39 \pm 2.54^{\mathrm{a}}$ & $56.97 \pm 1.27^{\mathrm{b}}$ & $59.51 \pm 8.21^{\mathrm{b}}$ & $60.86 \pm 4.23^{\mathrm{b}}$ \\
APD & $80.28 \pm 1.23^{\mathrm{a}}$ & $78.11 \pm 2.28^{\mathrm{b}}$ & $80.37 \pm 1.61^{\mathrm{a}}$ & $81.66 \pm 1.65^{\mathrm{a}}$ & $78.55 \pm 2.62^{\mathrm{b}}$ & $77.97 \pm 2.57^{\mathrm{b}}$ & $79.12 \pm 2.56^{\mathrm{b}}$ \\
\hline
\end{tabular}

Means with \pm SD are values of triplicate groups. Figures in the same row with different superscripts are significantly different (one-way ANOVA followed by DMRT, $p<0.05)$. $R D$ reference diet, $T D$ test diet, $F C R$ feed conversion ratio, $P E R$ protein efficiency ratio, $P R V$ protein retention value, $L R V$ lipid retention value, $A R V$ ash retention value, $\mathrm{Nm}$ nitrogen metabolism, $A P D$ apparent protein digestibility 
Table 5 Effect on HSI, RLG and DSI of L. rohita fingerling after 100 days of feeding

\begin{tabular}{llllllll}
\hline & RD & TD & & & \\
\cline { 2 - 7 } & D1 & D2 & D3 & D4 & D5 & D6 & D7 \\
\hline HSI & $0.71 \pm 0.06$ & $0.71 \pm 0.11$ & $0.70 \pm 0.10$ & $0.71 \pm 0.07$ & $0.72 \pm 0.10$ & $0.72 \pm 0.11$ & $0.70 \pm 0.09$ \\
RLG & $3.43 \pm 0.07$ & $3.43 \pm 0.10$ & $3.44 \pm 0.06$ & $3.43 \pm 0.09$ & $3.42 \pm 0.10$ & $3.45 \pm 0.06$ & $3.43 \pm 0.08$ \\
DSI & $4.25 \pm 0.08$ & $4.28 \pm 0.13$ & $4.28 \pm 0.11$ & $4.26 \pm 0.08$ & $4.30 \pm 0.06$ & $4.29 \pm 0.13$ & $4.26 \pm 0.09$ \\
\hline
\end{tabular}

Means with $\pm \mathrm{SD}$ are values of triplicates groups. Figures in the same row with same superscripts are not significantly different (one-way ANOVA, $p>0.05$ ). RD reference diet, $T D$ test diet, $H S I$ hepatosomatic index, RLG relative length of gut, DSI digest-somatic index

efficiently used in fish feed formulation (Dossou et al., 2018; Webster et al., 1992, 1995). However, animal-derived protein sources are found to be better than plant sources because of higher amino acid compatibility and less content of anti-nutritional factors. The present study demonstrated the feasibility of the use of a grasshopper $O$. hyla hyla meal as an alternate protein source in feed formulation for an Indian major carp, $L$. rohita. The dietary protein requirement for $L$. rohita has been suggested to be $30-35 \%$ to obtain high feed efficiency and growth performance (Chakrabarty, Chowdhry, \& Chakrabarty, 1999; Rangacharyulu et al., 2000). Hence, 33\% dietary protein was considered for the preparation of experimental diets. The major ingredients from plant protein sources like SBM and MOC were taken in a fixed proportion for all diets and keeping in mind that if quality of feeds differed that would be due to substitution of FM by OM. The results after 100 days feeding experiments clearly revealed that acceptability of the feeds was not affected due to OM incorporation rather feeding on these diet fish grew significantly $(p<0.05)$ from their initial wet weight and length. The results showed that diets (D2, D3 and D4) with up to $50 \%$ replacement of FM by OM did not affect food consumption, feed utilisation and growth performances of the fish.

Condition factor indicates health status of the fish, and it is used to determine the feeding activity (Lizama \& Ambrosio, 2002). In the present study, condition factor of the fish of different feeding groups showed no significant variations. This indicated that OM-incorporated diets had no adverse effect in maintaining good health status of the fish. The growth performances viz., wet weight gain (\%) and length gain (\%), SGR (\% day $\left.{ }^{-1}\right)$ and ADG (\%) of the fingerlings fed on D2, D3 and D4 diets were almost similar to the D1 fed fish. Another work with insect-containing diets (Begum, Chakraborty, Zaher, Abdul, \& Gupta, 1994) showed that feeding with the diets containing $50 \%$ of its protein contributed by silkworm pupae resulted significantly better SGR, FCR and PER for L. rohita. FCR and PER indicate nutritional value of feeds available for the growth of fish (De Silva \& Anderson, 1998). The result of the present study showed that FCR and PER values of the diets, D3 and D4, were similar to the reference diet (D1) but the results were unsatisfactory when more than 50\% FM was replaced by OM. This may be due to improper balance of required amino acids. Thus, up to $50 \%$ replacement of FM by OM could be successfully implemented.

Nutritional value of a feedstuff depends on its digestibility. According to Salim, Aziz, Sultan, and Mustafa (2004), digestible ingredients maximise nutrient availability and growth of fish and check the waste production. Digestibility of FM in carps varies from $80-85 \%$ depending on the origin and processing of fishmeal (Ogino \& Chen, 1973). Bairagi, Ghosh, Sen, and Ray (2002) observed 89\% apparent protein digestibility (APD) of a 40\% FM containing diet fed to L. rohita fingerlings. APD of the present formulated feeds fed to $L$. rohita fingerlings were found to be from 77.9 to $81.6 \%$ having no significant differences. Similar results were obtained by Mukhopadhyay and Ray (1999) where they observed that APD of copra meal substituted diets of $L$. rohita were from 81.1 to $88.9 \%$. Nitrogen metabolism of L. rohita fed on the diets D3 and D4 did not differ significantly to that D1 diet. Moreover, OM-incorporated

Table 6 Carcass composition (\% of wet weight) of L. rohita fingerlings after 100 days feeding

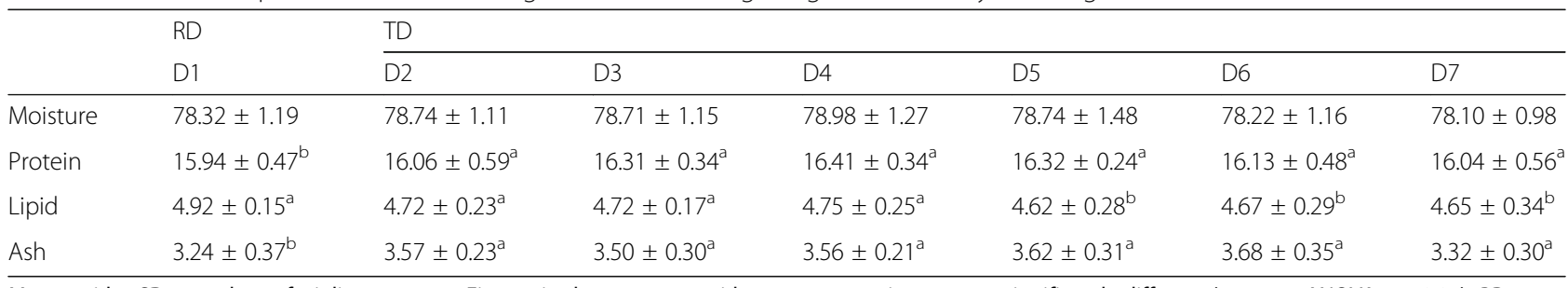

Means with \pm SD are values of triplicate groups. Figures in the same row with same superscripts are not significantly different (one-way ANOVA, $p>0.05$ ). RD reference diet, $T D$ test diet 
diets had no negative effect on the protein, lipid and ash retention.

HSI increases due to conversion of excess glucose into glycogen and its deposition or decreases due to depletion of glycogen storage in case nutrient deficiency (Debnath et al., 2007). In this study, HSI of the fish fed on reference diet and test diets neither increased nor decreased and that indicated no nutrient deficiency was occurred by feeding on test diets. Moreover, test diets caused no adverse effects on RLG and DSI of the fish. The carcass composition often determines the flesh quality of fish and it depends on the feeding status. Feed quality and feeding rate affect the body composition of fish (Adebayo, Balogun, \& Fagbenro, 2000; Hassan \& Jafri, 1994; Khan, Jafri, \& Chadha, 2004; Lovell, 1992; Panda, Mishra, \& Samantaray, 1999). Hence, carcass composition and organoleptic properties of the fish flesh are taken into account during quality feed formulation. The present study revealed that protein and lipid content in the flesh were improved in D2, D3 and D4 diet fed fish than the fish fed on reference diet.

\section{Conclusion}

The results of this study revealed that up to $50 \%$ replacement of FM by OM meal in the diets of L. rohita fingerlings did not affect the growth performances, feed utilisation parameters and flesh quality of the fish. Hence, the short horn grasshopper O. hyla hyla may be a new protein-rich ingredient in aqua feed formulation and may be used as partial replacer of fishmeal in the compounded diets of fish.

\section{Abbreviations \\ \%ADG: Percent of average daily growth; \%SGR: Percent of specific growth rate; ANOVA: Analysis of variance; APD: Apparent protein digestibility; CMC: Carboxy methyl cellulose; CO: Chromic oxide; CP: Crude protein; D: Diet; DO: Dissolved oxygen; DSI: Digesto-somatic index; FCR: Feed conversion ratio; FM: Fishmeal; $\mathrm{H}_{2} \mathrm{SO}_{4}$ : Sulphuric acid; HIS: Hepatosomatic index; K: Condition factor; LVR: Lipid retention value; ME: Metabolisable energy; MOC: Mustard oil cake; $\mathrm{NaOH}$ : Sodium hydroxide; NFE: Nitrogen-free extract; Nm: Nitrogen metabolism; OM: Oxya meal; PER: Protein efficiency ratio; PRV: Protein retention value; RB: Rice bran; RD: Reference diet: RLG: Relative length of gut; SBM: Soybean meal; SD: Standard deviation; TD: Test diet; WF: Wheat flour}

\section{Acknowledgements}

Authors are thankful to the Head, Department of Zoology, Visva-Bharati University, for providing necessary laboratory and infrastructural facilities and University Grants Commission, New Delhi, for financial support.

\section{Funding}

This study was supported by the grants of the University Grants Commission (UGC), Government of India in the form of a Major Research Project F. No. 40-358/2011(SR)

\section{Availability of data and materials}

Published data of this article may be used for academic and non-commercial research purposes.

\section{Authors' contributions}

SG designed and carried out the experiments, collected samples, involved in analysis and interpretation of data and manuscript writing. DKM suggested the concept of the work, designed the study and involved in interpretation of data and manuscript writing. Both authors read and approved the final manuscript.

\section{Ethics approval and consent to participate}

Rearing and handling of grasshoppers and cultivable fish used in this study have been conducted in compliance to the guideline of the 'Institutional Animal Ethics Committee' of Visva-Bharati University, India.

\section{Consent for publication}

Not applicable

\section{Competing interests}

The authors declare that they have no competing interests.

\section{Publisher's Note}

Springer Nature remains neutral with regard to jurisdictional claims in published maps and institutional affiliations.

Received: 23 January 2019 Accepted: 8 April 2019

Published online: 02 May 2019

\section{References}

Adebayo, O. T., Balogun, A. M., \& Fagbenro, O. A. (2000). Effect of feeding rates on growth, body composition and economic performance of juvenile clariid catfish hybrid (Clarias gariepinus $\times$ Heterobranchus bidorsalis). Journal of Aquaculture in the Tropics, 15, 109-117.

Alam, A. K., Maughan, E., \& Matter, W. J. (1996). Growth response of indigenous and exotic carp species to different protein sources in pelleted feeds. Aquaculture Research, 27(9), 673-679.

Alegbeleye, W. O., Obasa, S. O., Olude, O. O. Otubu, K. \& Jimoh, W. (2012). Preliminary evaluation of the nutritive value of the variegated grasshopper (Zonocerus variegatus L.) for African catfish Clarias gariepinus (Burchell. 1822) fingerlings. Aquaculture Research, 43(3), 412-420.

Anand, H., Ganguly, A., \& Haldar, P. (2008). Potential value of Acridids as high protein supplement for poultry feed. International Journal of Poultry Science, 7, 722-725.

AOAC (2005). Official methods of analysis, (18th ed., ). Maryland: Association of Analytical Chemists.

APHA (1990). Standard methods for the examination of water and waste water, (17th ed., ). New York: American Public Health Association.

Bairagi, A., Ghosh, S. K., Sen, S. K., \& Ray, A. K. (2002). Duckweed (Lemna polyrhiza) leaf meal as a source of feedstuff in formulated diets for rohu (Labeo rohita Ham.) fingerlings after fermentation with a fish intestinal bacterium. Bioresource Technology, 85, 17-24.

Balogun, B. I. (2011). Growth performance and feed utilization of Clarias gariepinus (Teugels) fed different dietary levels of soaked Bauhinia monandra (Linn.) seed meal and sun dried locust meal (Schistocerca gregaria). Zaria: Ph. D, Dept Biological Sciences, Faculty of Science, Ahmadu Bello University.

Begum, N. N., Chakraborty, S. C., Zaher, M., Abdul, M. M., \& Gupta, M. V. (1994). Replacement of fishmeal by low-cost animal protein as a quality fish feed ingredient for Indian major carp, Labeo rohita fingerlings. Journal of the Science of Food and Agriculture, 64, 191-197.

Chakrabarty, S. C., Chowdhry, S. A., \& Chakrabarty, S. (1999). Energy budget of Indian major carp, Labeo rohita fingerlings fed on diets with different protein levels. Asian Fisheries Science, 12, 297-308.

Dabrowski, K. R., Kok, L. Y., \& Takashima, F. (1986). How efficiently do fish larvae and juveniles swim? Comparative Biochemistry and Physiology Part A, 85, 657661.

De Silva, S. S., \& Anderson, A. (1998). Fish nutrition in aquaculture. London: Chapman and Hall.

Debnath, D., Pal, A. K., Sahu, N. P., Yengkokpam, S., Baruah, K., Choudhury, D., \& Venkateshwarlu, G. (2007). Digestive enzymes and metabolic profile of Labeo rohita fingerlings fed diets with different crude protein levels. Comparative Biochemistry and Physiology Part B, 146, 107-114.

DeFoliart, G. R. (1999). Insects as food: Why the Western attitude is important. Annual Review of Entomology, 44, 21-50. 
Divakaran, S., Leonard, G. O., \& lan, P. F. (2002). Note on the methods for determination of chromic oxide in shrimp feeds. Journal of Agricultural and Food Chemistry, 50, 464-467.

Dossou, S., Koshio, S., Ishikawa, M., Yokoyama, S., Dawood, M. A. O., Basuini, M. F. E., ... Zaineldin, A. I. (2018). Growth performance, blood health, antioxidant status and immune response in red sea bream (Pagrus major) fed Aspergillus oryzae fermented rapeseed meal (RM-Koji). Fish and Shelfish Immunology. https://doi.org/10.1016/j.fsi.2018.01.032.

Emehinaiye, P. A. (2012). Growth performance of Oreochromis niloticus fingerlings fed with varying levels of migratory locust (Locusta migratoria) meal. Abeokuta: Bachelor of Aquaculture and Fisheries Management, Federal University of Agriculture

Finke, M. D. (2013). Complete nutrient content of four species of feeder insects. Zoo Biology, 32, 27-36. https://doi.org/10.1002/zoo.21012.

Ganguly, A., Chakravorty, R., Das, M., Gupta, M., Mandal, D. K., Haldar, P., .. Moreno, J. M. P. (2013). A preliminary study on the estimation of nutrients and anti-nutrients in Oedaleus abruptus (Thunberg) (Orthoptera: Acrididae). International Journal of Nutrition and Metabolism, 5(3), 60-65.

Ganguly, A., Chakravorty, R., Sarkar, A., Mandal, D. K., Haldar, P., Ramos-Elorduy, J., \& Moreno, J. M. P. (2014). A preliminary study on Oxya fuscovittata (Marschall) as an alternative nutrient supplement in the diets of Poecilia sphenops (Valenciennes). PLoS One, 9(11), e111848. https://doi.org/10.1371/journal.pone.0111848.

Ghosh, S., Haldar, P., \& Mandal, D. K. (2014). Suitable food plants for mass rearing of the short-horn grasshopper Oxya hyla hyla (Orthoptera: Acrididae). European Journal of Entomology, 111(3), 448-452. https://doi.org/10.14411/eje.2014.038.

Ghosh, S., Haldar, P., \& Mandal, D. K. (2015). Biotic potential of a short-horned grasshopper Oxya hyla hyla Senville (Orthoptera; Acrididae) to assess it biomass producing capacity. Proceedings of the Zoological Society, 70(1), 46-51. https://doi. org/10.1007/s12595-015-0159-2.

Ghosh, S., Haldar, P., \& Mandal, D. K. (2016). Evaluation of nutrient quality of a short horned grasshopper, Oxya hyla hyla Serville (Orthoptera: Acrididae) in search of new protein source. Journal of Entomology and Zoology Studies, 4(1), 193-197.

Gur, N. (1997). Innovations in tilapia nutrition in Israel. Israeli Journal of Aquaculture - Bamidgeh, 49, 151-159.

Haldar, P., Das, A., \& Gupta, R. K. (1999). A laboratory base study on farming of an Indian grasshopper Oxya fuscovittata (Marschall) (Orhtoptera: Acrididae). Journal of Orthoptera Research, 8, 93-97.

Hassan, M. A., \& Jafri, A. K. (1994). Optimum feeding rate, and energy and protein maintenance requirements of young, Clarias batrachus (L.) a cultivable catfish species. Aquaculture Research, 25, 427-438.

Hassan, M. A., \& Khan, M. A. (1999). Efficacy of animal wastes as supplementary feed for Indian major carp, Labeo rohita, fingerling. Journal of the Inland Fisheries Society of India, 31, 52-57.

Jamabo, N. A., \& Alfred-Ockiya, J. F. (2008). Effects of dietary protein levels on the growth performance of Heterobranchus bidorsalis (Geoffroy-SaintHilaire, 1809) fingerlings from the Niger Delta. African Journal of Biotechnology, 7(14), 2483-2485.

Jauncey, K. (1982). The effects of varying dietary protein level on the growth, food conversion, protein utilization and body composition of juvenile tilapias (Sarotherodon mossambicus). Aquaculture, 27, 43-54.

Johri, R., Singh, R., \& Johri, P. K. (2010). Effect of different formulated plant and animal diet on hematology of Clarias batrachus Linn. under laboratory conditions. Biochemical and Cellular Archives, 10(2), 283-291.

Kaushik, S. J. D., Coves, G., Dutto, \& Blanc, D. (2004). Almost total replacement of fish meal by plant protein sources in the diet of a marine teleost, the European seabass, Dicentrarchus labrax. Aquaculture, 230, 391-404.

Khan, M. A., Jafri, A. K., \& Chadha, N. K. (2004). Growth and body composition of rohu, Labeo rohita (Hamilton), fed compound diet: Winter feeding and rearing to marketable size. Journal of Applied Ichthyology, 20, 265-270.

Lim, C. (1992). Full fat soybean meal utilization by fish. Asian Fisheries Science, 5, 181-187.

Lizama, M. D. L. A. P., \& Ambrosio, A. M. (2002). Condition factor in nine species of fish of the Characidae family in the upper Parana river floodplain, Brazil. Brazilian Journal of Biology, 62, 113-124.

Lovell, R. T. (1992). Comparison of satiate feeding and restricted feeding in channel catfish with various concentrations of dietary proteins in production ponds. Aquaculture, 103, 165-175.

Middleton, T. F., Ferket, P. R., Boyd, L. C., Daniels, H. V., \& Gallagher, M. L. (2001). An evaluation of co-extruded poultry silage and culled jewel sweet potatoes as a feed ingredient for hybrid Tilapia (Oreochromis niloticus $\times 0$. mossambicus). Aquaculture, 198(3), 269-280.
Moyle, P. B., \& Cech Jr., J. J. (1996). Fishes: An introduction to ichthyology, (3rd ed., ). Upper Saddle River: Prentice-Hall.

Mukhopadhyay, N., \& Ray, A. K. (1999). Utilization of copra meal in the formulation of compound diets for rohu, Labeo rohita, fingerlings. Journal of Applied Ichthyology, 15, 127-131.

Ogino, C., \& Chen, M. S. (1973). Protein nutrition in fish. V. Relation between biological value of dietary protein and their utilization in carp. Bulletin of the Japanese Society for the Science of Fish (Nippon Suisan Gakkaishi), 39(9), 955-959.

Ojha, M. L., Chadha, N. K., Saini, V. P., Damroy, S., Chandraprakash, \& Sawant, P. B. (2014). Effect of ethanolic extract of Mucuna pruriens on growth, metabolism and immunity of Labeo rohita (Hamilton, 1822) fingerlings. International Journal of Fauna and Biological Studies, 1(5), 01-09.

Panda, S., Mishra, K., \& Samantaray, K. (1999). Effect of feeding rate on the growth performance of Channa punctatus (Bloch) fry, and protein and energy requirement for their maintenance and maximum growth. Journal of Aquaculture, 7, 37-42.

Rangacharyulu, P. V., Giri, S. S., Paul, B. N., Yashoda, K. P., Rao, R. J., Mahendrakar, N. S., ... Mukhopadhyay, P. K. (2003). Utilization of fermented silkworm pupae silage in feed for carps. Bioresource Technology, 86(1), 29-32.

Rangacharyulu, P. V., Paul, B. N., Nandi, S., Sarkar, S., \& Mukhopadhyay, P. K. (2000). Effect of different protein and energy levels on growth, nitrogen metabolism and body composition of rohu (Labeo rohita). Journal of Aquaculture, 8, 17-24.

Rumpold, B. A., \& Schlüter, O. K. (2013). Nutritional composition and safety aspects of edible insects. Molecular Nutrition \& Food Research, 57, 802-823.

Salim, M., Aziz, I., Sultan, J. I., \& Mustafa, I. (2004). Evaluation of apparent digestibility of fish meal, sunflower meal and rice polish for Labeo rohita. Pakistan Journal of Life and Social Sciences, 2(2), 139-144.

Singh, P. K., Gaur, S. R., Pabitra, B., Sulochana, Smriti, S., \& Singh, S. (2005). Effect of protein levels on growth and digestibility in the Indian major carp, Labeo rohita (Hamilton) using slaughter house waste as the protein source. International Journal of Agriculture and Biology, 7(6), 939-941.

Spyridakis, P., Metailler, R., Gabaudan, J., \& Riaza, A. (1989). Studies on nutrient digestibility in European sea bass (Dicentrarchus labrax): 1. Methodological aspects concerning faeces collection. Aquaculture, 77(1), 61-70.

Subhadra, B., Lochmann, R., Rawles, S., \& Chen, R. (2006). Effect of fish-meal replacement with poultry by-product meal on the growth, tissue composition and hematological parameters of largemouth bass (Micropterus salmoides) fed diets containing different lipids. Aquaculture, 260(1), 221-231.

Subramanian, A., \& Balasubramanian, U. (2014). Effect of spirulina on growth and biochemical performance in common carp Catla catla and Labeo rohita (fingerlings). International Journal of Fisheries and Aquaculture, 4(3), 140-144.

Turker, A., Yigit, M., Ergun, S., Karaali, B., \& Erteken, A. (2005). Potential of poultry by-product meal as a substitute for fishmeal in diets for black sea turbot, Scophthalmus maeoticus: Growth and nutrient utilization in winter. Israeli Journal of Aquaculture -Bamidgeh, 57, 49-61.

Ueckert, D. N., Yang, S. P., \& Albin, R. C. (1972). Biological value of rangeland grasshoppers as a protein concentrate. Journal of Economic Entomology, 65, 1286-1288.

Wang, D., Shao-Wei, Z., Chuan-XI, Z., Zhang, Q., \& Chen, H. (2007). Nutritional value of the Chinese grasshopper Acrida cineria (Thunberg) for broilers. Animal Feed Science and Technology, 135, 66-74.

Watanabe, T., Verakunpiriya, V., Watanabe, K., Kiron, V., \& Satoh, S. (1997). Feeding of rainbow trout with non-fish meal diets. Fisheries Science, 63, 258-266.

Webster, C. D., Goodgame-Tiu, L. S., \& Tidwell, J. H. (1995). Total replacement of soybean meal, with various percentages of supplemental L-methionine, in diets for blue catfish (Ictalurusfurcatus) (Lesueu). Aquaculture Research, 26, 299-306.

Webster, C. D., Yancey, D. H., \& Tidwell, J. H. (1992). Effect of partially or totally replacing fish meal with soybean meal on growth of blue catfish (Ictalurus furcatus). Aquaculture, 103, 141-152. https://doi.org/10.1016/0044-8486(92)90408-D.

Xie, N. B., Feng, L., Liu, Y., Jiang, J., Jiang, W. D., Hu, K., .. Zhou, X. Q. (2011). Growth, body composition, intestinal enzyme activities and microflora of juvenile Jian carp (Cyprinuscarpio var. Jian) fed graded levels of dietary phosphorus. Aquaculture Nutrition, 17, 645-656.

Yang, Y., Xie, S., Cui, Y., Lei, W., Zhu, X., Yang, Y., \& Yu, Y. (2004). Effect of replacement of dietary fish meal by meat and bone meal and poultry byproduct meal on growth and feed utilization of gibel carp, Carassius auratus gibelio. Aquaculture Nutrition, 10, 289-294.

Yoshitomi, B., Aoki, M., \& Oshima, S. I. (2007). Effect of total replacement of dietary fish meal by low fluoride krill (Euphausia superba) meal on growth performance of rainbow trout (Oncorhynchus mykiss) in fresh water. Aquaculture, 266, 219-225. 